\title{
DYNAMIC REPAYMENT OF MORTGAGE LOANS: A SOLUTION FOR THE LOW-INCOME SECTOR?
}

\author{
W. R. Gevers \\ University of Stellenbosch Business School \\ PO Box 610, Bellville, 7535
}

\begin{abstract}
By using a dynamic installment repayment plan to finance a mortgage loan rather than the usual fixed installment financing, the threshold at which a prospective homeowner may enter the housing market may be lowered substantially. In this paper this method of financing will be evaluated to determine under which circumstances it could be used to help the low-income group to obtain housing, and also to highlight some of its deficiencies. Historic trends of income are also analysed to determine the income growth potential of the low-income sector. The income growth potential does not seem to distract from the potential of the dynamic repayment of mortgage loans.
\end{abstract}

\section{INTRODUCTION}

To discuss the financing of housing for the individual homeowner in an Operations Research environment may be frowned upon, but if research regarding the use of Operations Research in business is examined, one finds that concepts regarding the time value of money, such as net present value, are listed as possible operations research techniques both in South Africa (Wegner, 1983: 120-124) and abroad (Schumacher \& Smith, 1965: 1023-1027).

The individual homeowner often finances his home by putting down a deposit of say 20 percent of the purchase price and the remaining 80 percent by means of a mortgage bond which is repaid in fixed monthly installments (provided the interest rate remains constant) over a fixed length of time, say 20 years. Although 100 percent mortgage financing is provided by a number of financial institutions, this is normally only available to professional people or those who can supply some other form of security. Financial institutions who provide money for mortgage financing traditionally do not allow the borrower to spend more than 25 percent ( 30 percent is sometimes considered) of his gross household income on his installments. For the prospective home buyer this creates a twofold problem. In the first place he battles to save enough to put down as a deposit, otten finding that by the time he has saved what 
originally seemed to be enough, the selling prices, and hence the deposit, has increased, making his savings insufficient for a deposit. Furthermore he must then finance a larger bond requiring a larger installment which may exceed 25 percent of his current household income. Yet a year or two hence his income will have grown, due to wage or salary adjustments to counter the effect of inflation or due to advancement, to such an extent that he can afford the dwelling that was originally envisaged.

It is doubtful whether there are any strong arguments against the use of some method of limiting the amount spent by a person on housing as many financial institutions do. One can argue about whether the breadwinner's income only, or the total household income should be used in determining the cut off point, or whether net or gross income should be used, and what percentage to use, but that is of no concern in this paper. Whatever cut off percentage is used, it should be determined in such a way that one should be able to maintain that percentage for the total duration of the repayment of the bond. Although this is probably the principle used by financial institutions in determining the maximum affordable bond repayment, it is only applied on the borrower's current income to determine a fixed installment. Thus potential growth in income is ignored in determining the installment.

If one were to allow the bond repayment installment to grow over time, one would come closer to maintaining a fixed percentage of income to be spent on housing. A growing bond repayment installment has the advantage that for a particular amount borrowed and repaid over a fixed period, the initial installment is lower than the equivalent fixed installment, thus reducing the required income level when purchasing a home. Although later installments will become higher than the fixed installment, income should have grown to such an extent to still make the housing affordable.

Although the principle of dynamic repayment of a mortgage loan is not new (Jorgenson, 1977), it is important to investigate under what conditions this method of financing housing is viable, or perhaps even a better alternative to the fixed repayment schedule.

The results of this investigation are of a general nature and could be applied to any prospective home buyer. It is, however, of particular importance to the low-income sector where adequate housing cannot be obtained by merely lowering the prospective home buyer's requirements, but the basic need is to finance some form of shelter.

As the emphasis is on investigating a method of home financing for the low-income sector of the population, it is also important to determine whether and to what extent this sector's income has increased over the last number of years. This should indicate whether a dynamic repayment schedule could be affordable.

\section{DELIMITATIONS}

If the dynamic installment or progressive annuity method of financing is considered as an alternative to the fixed installment method of financing a home, a number of parameters must be investigated in depth. The term over which the bond is repaid and the governing interest rate are factors which are common to both methods of financing, but the growth rate of the installment, and the period over which the installment is allowed to grow are factors specific to the dynamic installment method. When compared to the fixed annuity, the progressive annuity has lower initial installments, but higher later installments. 
The extent of the initial reduction and the final increase need to be evaluated. Furthermore, since the initial installments are lower than the fixed annuity installment for the same size loan, initial installments may not be large enough to cover the interest on the loan and outstanding interest must be capitalised into the loan. The extent to which a loan may grow needs to be investigated.

The above mentioned factors pertaining to the method of progressive annuity financing are analysed and discussed in this paper. No attempt is made to address the problems of providing homes to many low-income inhabitants of South Africa and how these homes could be financed. The results of this paper should sel some guidelines as to when dynamic installments are viable as a method of financing a mortgage bond.

The income growth potential of a number of categories of people are estimated by evaluating past income patterns over time. This will give an indication of the extent to which incomes have kept pace with inflation over the last number of years. If incomes keep pace with inflation, a dynamic installment plan of mortgage financing should be affordable.

The paper also does not evaluate the increase or decrease in the value of the property acquired as a security to the lender, nor the effect that this type of financing may have on the operations of the lender.

\section{THE DATA AND ITS TREATMENT}

\subsection{The data}

The data for the evaluation of the dynamic installment payback model was generated by a model developed for this purpose and discussed in section 3.2. Income data was retrieved from the Standard Bank's Corporate Access Terminal System (CATS) as well as from the salary surveys conducted by FSA-Contact (Pty) Ltd who publish the Peromnes income surveys biannually. The Consumer Price Index was retrieved from statistics published by the Department of Statistics and CATS.

\subsection{The model}

The calculation of the periodic payment for a fixed installment type of loan is a simple procedure which has been programmed on most business calculators. The calculation of the initial payment for the repayment of a loan using the progressive annuity method can, however, not be accomplished using a single formula. The net present value of the periodic payments (which are not constant) at the interest rate quoted, is equal to the amount borrowed (that is the loan). Since it is not possible to convert a net present value to a string of variable cash flows, it is necessary to start with an arbitrary initial installment and calculate the subsequent installments using the installment growth rate. The loan amount (i.e. the amount that will actually be borrowed) is then divided by the net present value of this string of cash flows to give a factor. The assumed initial and all following installment are subsequently multiplied by the factor, yielding the correct installment plan.

The above process was simulated using the LOTUS 1-2-3 spreadsheet package. The model is documented in Appendix A. Provision was made for five input parameters, namely the size of the loan, the term of repayment of the loan, the interest rate, the installment growth rate and the period during which the installment may grow. With the use of a macro it was possible to automate the calculations. 
A further macro was developed to automatically evaluate a whole range of input parameters.

The model was developed to calculate an annual installment rather than a monthly installment. Although monthly compounding of interest is more accurate, the errors involved in compounding annually are smait. The principles involved in dynamic instaliment financing are clearly illustrated, whether one uses annual or monthly compounding. In the same vein an arbitrary loan amount of R1 000 is used to illustrate the principles, and no attempt has been made to determine the size of an actual home loan.

\section{RESULTS}

\subsection{Effect of progressive annuity bond repayments}

Figure 1 shows the outstanding balance of a loan of $\mathrm{R} 1000$ repaid over 20 years at interest rate of $14 \%$ and $20 \%$ for a fixed installment and an installment that grows by $10 \%$ per year for the full term of the loan. When the interest rate is $14 \%$, the initial installment is reduced by $48,1 \%$ (from R150,99 to $R 78,36$ ). but the final installment is increased by $217,4 \%$ to R479,21. At the current high level of interest of $20 \%$, the initial installment is decreased by $40,9 \%$, while the final installment is increased by $261,2 \%$. At $14 \%$ interest the loan grows to a maximum amount outstanding of $\mathrm{A} 1536,4611$ years after repayment of the loan is commenced (R1 909,90 after 13 years at $20 \%$ interest).

The reduction in initial installment is at least $40 \%$ even with high interest rates, and this could have a significant influence in making housing more affordable. The final installment, however, is more than $200 \%$ more than the fixed installment for the same size loan. This gives rise to concern over whether the borrower's income will have grown to the same extent as the installment has to keep the housing affordable. If one were to be conservative, and to keep the housing affordable it seems as if one should not consider installments that grow for the full term of the bond.

If the $\mathrm{A} 1000$ loan represented a $90 \%$ bond, the purchase price would have been $\mathrm{A} 1111$. If this value is allowed to grow at an arbitrarily chosen $1 \%$ per year, the lender woutd be at risk from the second year to the 15th year of the bond when the interest rate is at the lower level. Without security this would be too high a risk for any institution to bear. Thus in considering alternative circumstances under which progressive annuity type of installments could be feasible, the risk to the lender must be taken into account. This risk is clearly a function of the value of the property - the faster the property increases in value, the lower the risk. Since very little is known about the resale value of low-income housing, it is best to be conservative and allow for low rates of increase in value.

In figures 2 and 3 the same conditions as above are considered, except that the installment is only allowed to grow for 10 years. Various installment growth rates are shown. The maximum amount outstanding is reduced, and it occurs earlier when the growth rate is lower. Yet high installment growh rates still yield sizable maximum amounts outstanding.

Longer periods of installment growth also yield maximum outstanding amounts which are large compared to the size of the initial loan if the installment growth rate is kept fixed as shown in figures 4 and 5 where this rate was fixed at $6 \%$. If one wants the loan to reduce to its original size after approximately 10 years, then the installment should not be allowed to grow for longer than 10 years. 


\subsection{Term of loan}

It is known from fixed annuity bond repayments that a longer term of repayment generally leads to a lower installment, but that the reduction in installment with longer repayment periods is small when the interest rates are high. In order to evaluate this effect on dynamic instaliments, a repayment plan in which the installments grow by $6 \%$ annually for the first 10 years was analysed for loan terms of 15 to 30 years and interest rates of $10 \%$ to $20 \%$. The initial and final installments are expressed as a percentage of the 20 year term installment in tables 1 and 2 respectively.

Table 1 : Initial installment relative to 20 year term installment for a growth rate of $6 \%$ for 10 years

\begin{tabular}{|rrrrrrr|}
\hline & & \multicolumn{5}{c|}{ Interest rate } \\
Term & $10 \%$ & $12 \%$ & $14 \%$ & $16 \%$ & $18 \%$ & $20 \%$ \\
& & & & & & \\
15 & $116 \%$ & $113 \%$ & $111 \%$ & $109 \%$ & $107 \%$ & $106 \%$ \\
20 & $100 \%$ & $100 \%$ & $100 \%$ & $100 \%$ & $100 \%$ & $100 \%$ \\
25 & $92 \%$ & $94 \%$ & $95 \%$ & $96 \%$ & $97 \%$ & $98 \%$ \\
30 & $88 \%$ & $.91 \%$ & $93 \%$ & $95 \%$ & $96 \%$ & $97 \%$ \\
\hline
\end{tabular}

Table 2 : Final installment relative to 20 year term installment for a growth rate of $6 \%$ for 10 years

\begin{tabular}{|c|c|c|c|c|c|c|}
\hline \multirow[b]{2}{*}{ Term } & \multicolumn{6}{|c|}{ Interest rate } \\
\hline & $10 \%$ & $12 \%$ & $14 \%$ & $16 \%$ & $18 \%$ & $20 \%$ \\
\hline 15 & $112 \%$ & $110 \%$ & $108 \%$ & $106 \%$ & $105 \%$ & $104 \%$ \\
\hline 20 & $100 \%$ & $100 \%$ & $100 \%$ & $100 \%$ & $100 \%$ & $100 \%$ \\
\hline 25 & $94 \%$ & $95 \%$ & $96 \%$ & $97 \%$ & $98 \%$ & $98 \%$ \\
\hline 30 & $90 \%$ & $93 \%$ & $95 \%$ & $96 \%$ & $97 \%$ & $98 \%$ \\
\hline
\end{tabular}

From the tables it is clear that with interest rates as low as $12 \%$ per year and lower, installments may be reduced by $10 \%$ if the term of the loan is extended from 20 years to 30 years. At higher interest rates the reduction in installment with a longer term is much less and is probably not warranted if one considers the disadvantage of the longer commitment.

Current interest rates are generally in the order of $20 \%$ per year and if real interest rates are here to stay, it is unlikely that interest rates will drop much lower than $14 \%$ (unless inflation is curbed). Under those circumstances there is little advantage in extending the term of the loan beyond 20 years and all further discussion is based on loans repayable over that period.

\subsection{Initial and final installments}

Figures 6 and 7 show the initial and final installments plotted against the installment growth rate for a number of different periods of installment growth. The loan amount is $\mathrm{A} 1000$ to be repaid over 20 years 
at $20 \%$ interest rate.

From figure 6 it can be seen that a substantial decrease in initial installment may be effected by a growth period of only 5 years. With a $6 \%$ growth rate for 5 years the initial installment is reduced by $16 \%$ while the maximum outstanding balance is only $7,7 \%$ more than the initial loan. The installment is reduced by $30 \%$ if the growth rale is $12 \%$ for 5 years and in this instance the maximum amount oulstanding is $18,4 \%$ more than the amount borrowed.

If the period of installment growth is increased to 10 years, the initial installment is reduced by $22 \%$ with a $6 \%$ installment growth rate while the maximum amount outstanding on this loan is $22.6 \%$ higher than the initial loan. The comparative figures at the lower interest rate of $14 \%$ are a reduction of $26 \%$ with a maximum outstanding amount increased by a mere $11,4 \%$. This does illustrate that the dynamic repayment method's advantages are somewhat curtailed by higher levels of interest.

When the installment growth is increased to $10 \%$ for 10 years the outstanding balance on the loan increases to $145,7 \%(126,4 \%$ at $14 \%$ interest) of the initial loan, which seems excessive. The risk to the lender becomes a factor that needs to be considered. Installment growth rates higher than $6 \%$ when the interest rate is $20 \%$ and $10 \%$ when the interest rate is $14 \%$ over a period of 10 years thus do not seem viable.

The relatively close spacing of the lines depicting longer periods of installment growth in Figure 6 clearly indicates that there is little to be gained by extending the period of growth beyond 10 years. The detrimental effect on the final installment for longer growth periods is also emphasised by the divergence of the relevant lines in Figure 7.

The final installment that the borrower could afford depends entirely on the income growth potential of the borrower. In order to be conservative one should limit the installment growth rate to a fairly low percentage. and at the same time ensure that the final installment does not become too large. If a final installment of $50 \%$ more than the fixed annuity installment is considered to be affordable, then the final installment should not exceed approximately R308. If the installment is allowed to grow for 15 years, then the growth rate should not exceed $4 \%$ to ensure that this value is not exceeded. For a 10 year growth period a growth rate of approximately $7,5 \%$ could be used, while with a 5 year growth period, a growth rate of more than $16 \%$ could be used. Such a high growth rate seems to be more than the income growth rate of the borrower (illustrated in 4.5 below) and is likely to make the housing unaffordable after a few years. Yet higher installment growth levels maintained for a shorter period effect a larger reduction in initial installment, yielding the better benefit to the potential homeowner.

It is thus clear that a substantial reduction in initial installment can be effected without causing the final installment to become too large and at the same time limiting the size of the loan to fair proportions. An ideal mix between growth rate and period of growth should thus be strived for, with the emphasis on the installment growth rate.

\subsection{Risk to lender}

In Figure 8 the maximum amount owing on the loan is plotted against the number of years of growth 
of the instaliment for a number of different installment growth rates. As before, the amount borrowed amounts to $\mathrm{A} 1000$ repaid over 20 years at an interest rate of $20 \%$. The graph also shows the year in which the maximum amount owing occurs.

From this graph too it is clear that installment growth rates exceeding $6 \%$ for periods of 10 years and longer yield large outstanding amounts occurring long after repayments commence. Even with a fair growth in property value, these large outstanding amounts would probably be unacceptable to the lender. High growh rates for shorter periods or lower growth rates for longer periods have maximum amounts owing at acceptable levels.

If the lender wants to limit his risk, then the maximum amount owing on the loan should not exceed the value of the property, assurning no growth in the value of the property. If it is assumed that the $\mathrm{R} 1000$ loan represents a $90 \%$ bond, then the value of the property is equal to R1 111 . Figure 9 shows the installment growth rate plotted against the interest rate for various periods of installment growth and loans that have a maximum outstanding balance equal to A1 111. From the graph it is clear that even with the current high interest rate a fair installment growth rate can be maintained for a short period such as 5 years. If the lender wants to limit his risk in the above manner and the instaliment grows for 10 years at the current interest rate of $20 \%$, the installment growth rate is limited to somewhat less than $4 \%$. Under these circumstances the initial installment is $15 \%$ lower than the comparable fixed installment. A shorter growth period results in a higher installment growth rate for the same interest rate. This usually leads to a larger reduction in initial installment and a smaller final installment and is thus to be recommended.

\subsection{Income growth patterns}

In order to evaluate the longer term trend in income, the per capita average monthly earnings figures for three arbitrarily chosen industries and for the three listed population groups was extracted from the time series on CATS. The consumer price index: all items for both the low-income group and all income groups was extracted from the same source. The geometric mean annual increase in earnings and that of the CPI (all income groups) over periods of 10 and 13 years ( 15 years for the retail trade) are shown in Table 3.

Table 3 : Annual increase in per capita average monthly earnings

\begin{tabular}{|c|c|c|c|c|c|c|}
\hline \multirow[b]{2}{*}{ Start } & \multirow{2}{*}{$\begin{array}{l}\text { Year } \\
\text { End }\end{array}$} & \multirow{2}{*}{$\begin{array}{l}\text { Year } \\
\text { Industry }\end{array}$} & \multicolumn{4}{|c|}{ Population group } \\
\hline & & & All & Whites & Blacks & CPI \\
\hline 1973 & 1988 & Retail trade & $13,4 \%$ & $13,2 \%$ & $14,9 \%$ & $13,6 \%$ \\
\hline 1975 & 1988 & Manufacturing & $15.7 \%$ & $14,3 \%$ & $17,6 \%$ & $13,7 \%$ \\
\hline 1975 & 1988 & Construction & $13,6 \%$ & $14,3 \%$ & $13,3 \%$ & $13,7 \%$ \\
\hline 1978 & 1988 & Rètail trade & $14,7 \%$ & $14,7 \%$ & $16,3 \%$ & $14,5 \%$ \\
\hline 1978 & 1988 & Manufacturing & $16,3 \%$ & $15,1 \%$ & $18,1 \%$ & $14,5 \%$ \\
\hline 1978 & 1988 & Construction & $14.2 \%$ & $12,3 \%$ & $10,9 \%$ & $14,5 \%$ \\
\hline
\end{tabular}


From the table it is clear that in general for all population groups the increase in earnings has kept pace with inflation as measured by the CPI. There is little difference between the population groups, although the black population seem to have received slightly higher increases. The construction industry has fared worst, with the mean annual increase over 10 years trailing the CPI by a number of percentage points. Nevertheless a $10 \%$ per year increase has been maintained for 10 years and longer.

The above comparison was made relative to the all income group $\mathrm{CPI}$ and not relative to the low-income group CPl. It was found that these two indices are almost identical, with the low-income group CPI currently at a lower level than the all income group CPI. This is clearly illustrated in Figure $\mathbf{1 0}$ which shows the difference between the two indices over time.

The figures reported in Table 3 contain a large amount of aggregation which makes it impossible $\mathbf{t o}_{3}$ distinguish between the low-income group and others. In order to make this distinction, the median basic monthly remuneration for all incumbents in the salary grades 19 and 15 of the biannual Peromnes salary survey were extracted and analysed. Salary grade 19 is the lowest grade, while salary grade 15 represents the lowest grade in which white workers fall. The basic income is analysed since it is the best representation of cash received. The total income, which includes fringe benefits, actually displayed a higher rate of increase than the basic income.

Figure 11 depicts the cumulative six-monthly increase in income for both salary groups and the CPI. From the figure it can be seen that the increase in income of the lowest income group over the last six years has outperformed the CPI. In fact it is clear that the low-income group's income seems to keep up with inflation. Although Ashburner (1986: 8) in analysing income over the period July 1981 to July 1986 did not find that incomes kept pace with the CPI, it must be emphasized that she did not focus specifically on the low-income group. Nevertheless it was found that black incomes increased by $92 \%$ of the $\mathrm{CPI}$.

It thus seems safe to assume that when inflation as measured by the CPI is increasing at more than $10 \%$ per year, the low-income group will experience an increase in income of up to $10 \%$ per year. This seerns to make the dynamic repayment of a mortgage loan affordable.

\section{CONCLUSIONS AND RECOMMENDATIONS}

A model was developed to evaluate the usefulness of the dynamic instaliment method of loan repayment for prospective homeowners. From the analysis it is clear that a substantial reduction in initial installment may be effected without placing too large a burden on the homeowner at a later stage, and at the same time keeping the lender's risk at an acceptable low level. At the current high interest rate of $20 \%$ the initial installment may be reduced by $21 \%$ by letting the installment grow for 5 years at a rate of $8 \%$ without the loan exceeding the value of the property ( $90 \%$ bond). At a lower $14 \%$ interest rate, a $34 \%$ reduction in initial installment may be effected by letting the installment grow by $12,7 \%$ for 5 years, again without the loan exceeding the value of the property.

In order to limit the risk to the lender, installments should not be allowed to grow for more than 10 years, with 5 years of installment growth being preferable. A shorter period of growth at a higher growth rate has a more beneficial effect on the initial installment than a longer period of growth at a lower growth 
rate.

There is little benefit in extending the term of the loan to periods exceeding 20 years if the interest rate is $14 \%$ or higher.

An analysis of income patterns over the past number of years indicates that income levels of the low-income group seem to keep up with the increase in the CPI, or at most trail the CPI by at most a percentage point. This appears to indicate that the dynamic repayment method should be affordable.

Although, based on this analysis, the dynamic repayment of mortgage loans seems like a feasible method of financing a home, a number of aspects still require further investigation. Some of these are the following.

Since the initial installments using a dynamic repayment plan do not cover the full interest charge, the financier who provided the mortgage money may not be earning a sufficient income on the money provided. This possible detrimental effect on the profitability of the financier, albeit only during the initial growth phase of the repayment schedule, needs to be investigated further.

The lender may also seek some form of surety against a possible default by the homeowner when interest is being accumulated into his loan account. Under the current moratorium scheme announced by the Government to help homeowners cope with the high interest rates (Finansies \& Tegniek, 1989: 18), the Government itself provides the surety. Who should provide the surety if the dynamic repayment of mortgage loans became common practice, is an open question. Perhaps private enterprise through the homeowners' employers should bear this risk.

The extent to which the value of the property which is acquired by the low-income group, increases or decreases, is an unknown factor. For the analysis contained in this paper it was assumed that there was no movement in value over time. It is more likely that as the $C P$ Increases, building costs will also increase. As a result the value of used housing is also likely to increase. The order of this movement needs to be investigated further for an evaluation of the risk involved in this method of mortgage repayment.

\section{Acknowledgment}

The author is indebted to FSA Contact (Pty) Ltd who provided the Peromnes data, and to Mr DJ Joubert who suggested the analysis which is contained in this paper. 


\section{REFERENCES}

Ashburner, J. 1986. Salary and wage trends over the past year. IPM Journal. October, 8-10.

Finansies \& Tegniek. 1989. Verligting vir huiseienaars: gesond of nie? 42(23), 9 June, 18.

Jorgenson, N.O. 1977. Housing finance for the low-income groups. Rotterdam : Bouwcentrum.

Schumacher, C.D. \& Smith B.E. 1965. A sample survey of industrial operations research activities II. , Operations Research. 13, 1023-1027.

Wegner, T.A. 1983. A survey of quantitative methods in South African management. South African Journal of Business Management. 14(3), 120-124.

Figure 1:

Outstanding loan and value vs time

R1000 over 20 years, $10 \%$ growth

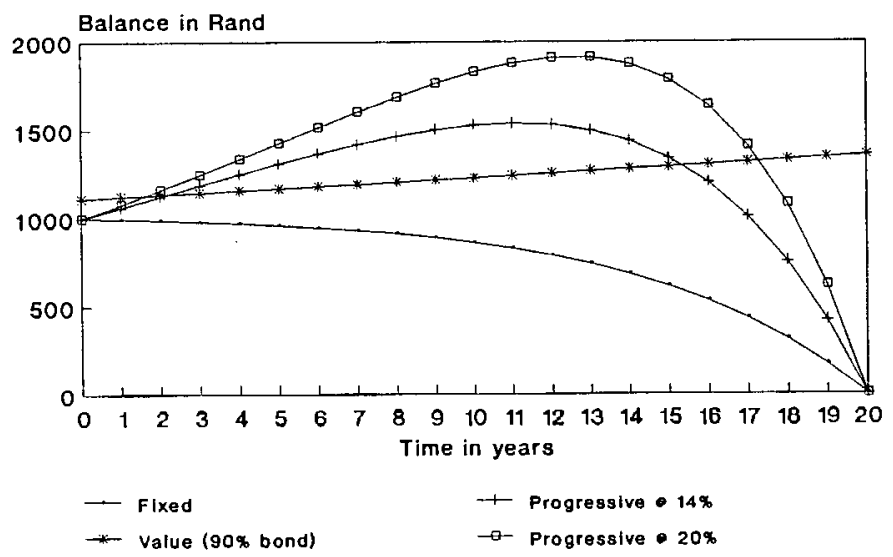


Figure 2 :

Outstanding balance of loan vs time R1000 for 20 years $\$ 14 \%, 10$ year growth

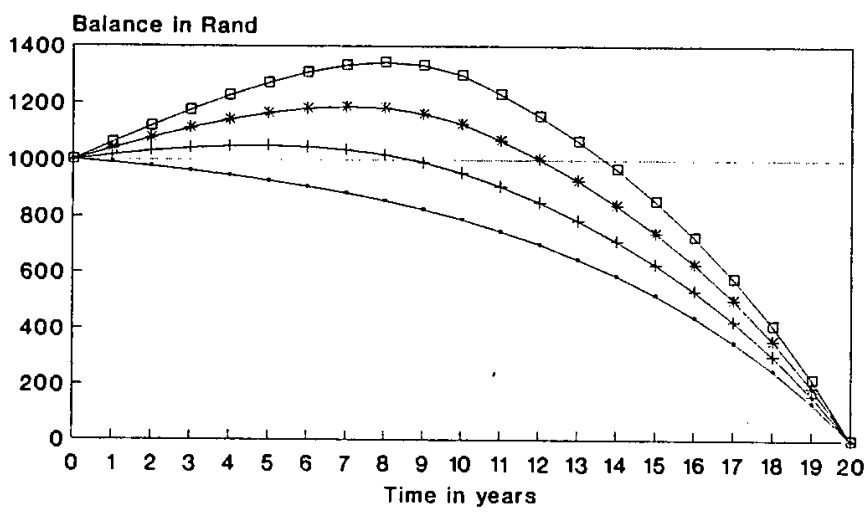

$\rightarrow$ Fixed $\rightarrow 4 \%-k 8 \% \rightarrow 12 \%$

Figure 3 :

Outstanding balance of loan vs time R1000 for 20 years $\$ 20 \%$, 10 year growth

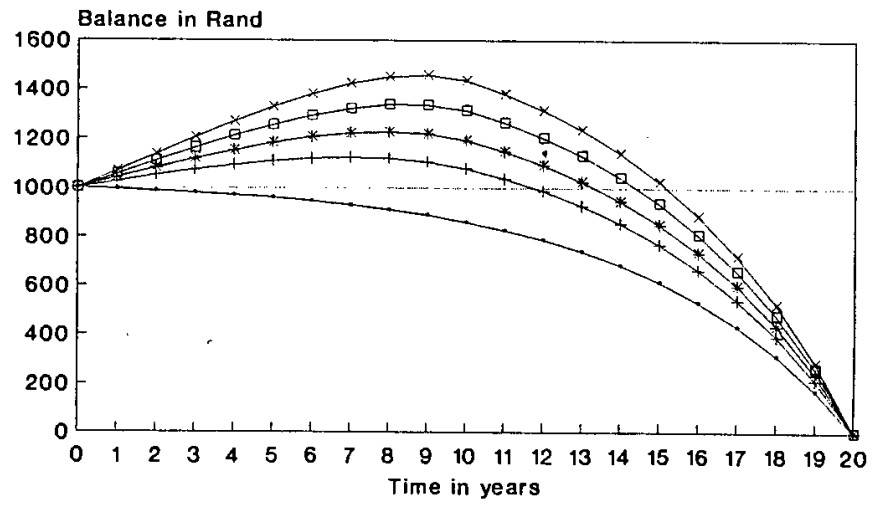

- Fixed $-4 \% \quad * 6 \% \rightarrow-8 \% \rightarrow 10 \%$ 
Figure 4:

Outstanding balance of loan vs time R1000 for 20 years $\$ 14 \%$, growth rate $6 \%$

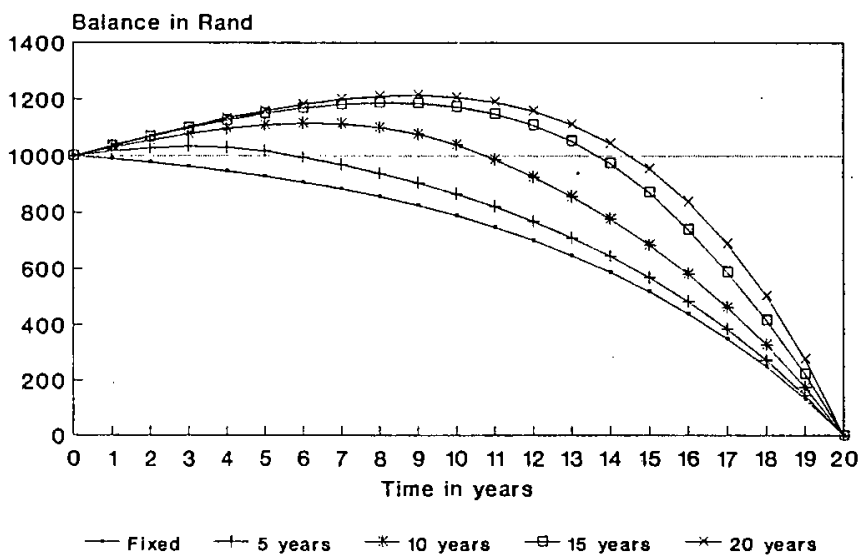

Figure 5:

Outstanding balance of loan vs time R1000 for 20 years $@ 20 \%$, growth rate $6 \%$

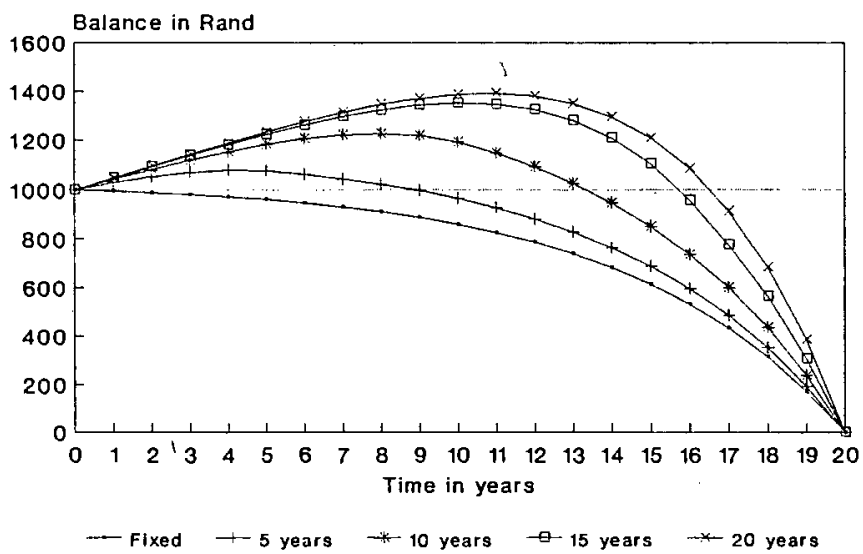


Figure 6 :

Initial installment vs growth rate R1000 $20 \%$ for 20 years
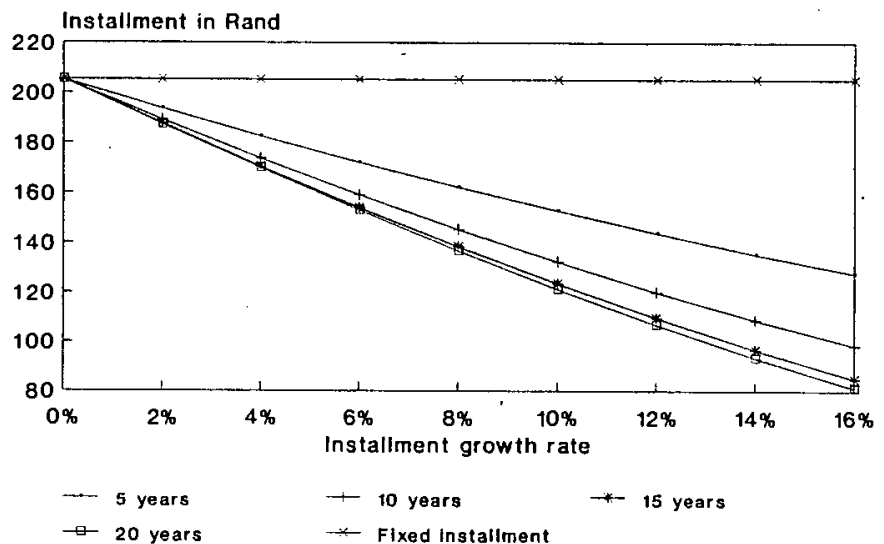

Figure 7 :

Final installment vs growth rate R1000 \& $20 \%$ for 20 years

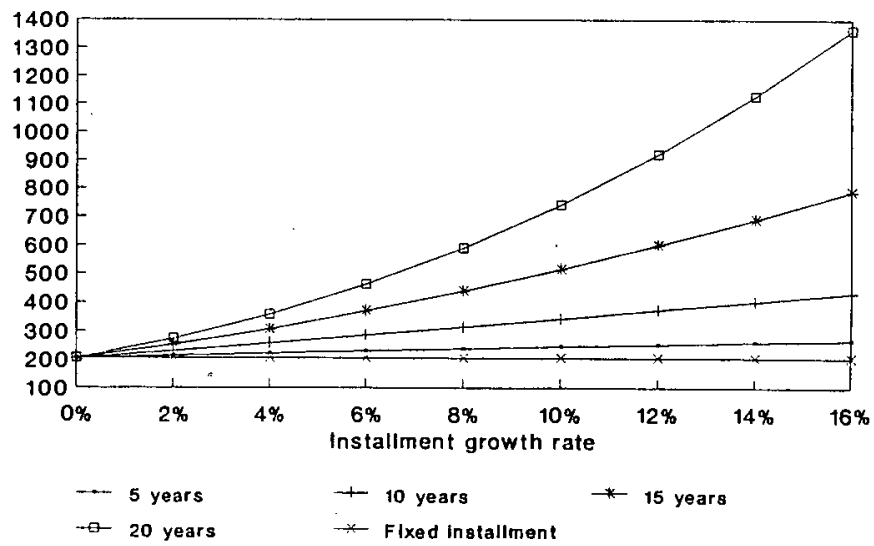


Figure 8 :

Maximum amount owing $R 1000 @ 20 \%$ for 20 years

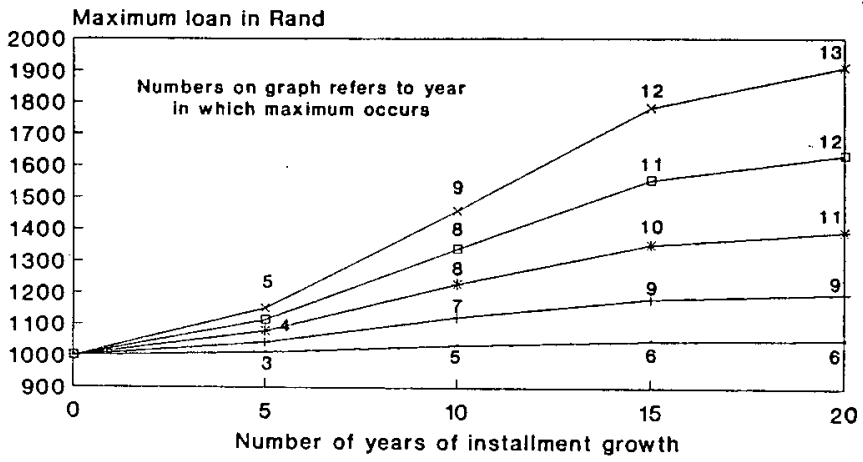

$\begin{array}{ll}-2 \% \text { Growth } & +4 \% \text { Growth } \quad * 6 \% \text { Growth } \\ \rightarrow-8 \% \text { Growth } & * 10 \% \text { Growth }\end{array}$

Figure 9: Installment growth rate vs interest rate 20 year term; maximum amount owing R1111 (R1111 value yields $\mathrm{R} 1000$ loan $90 \%$ bond)

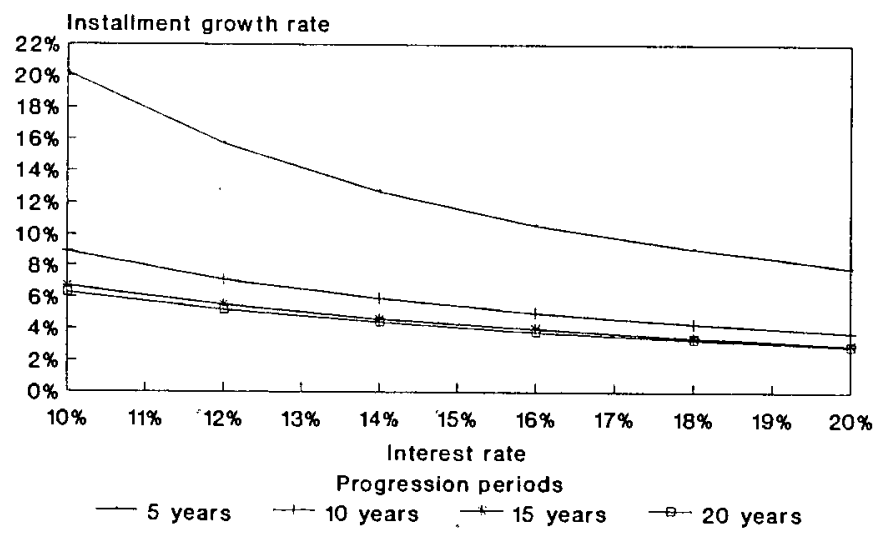


Figure 10 :

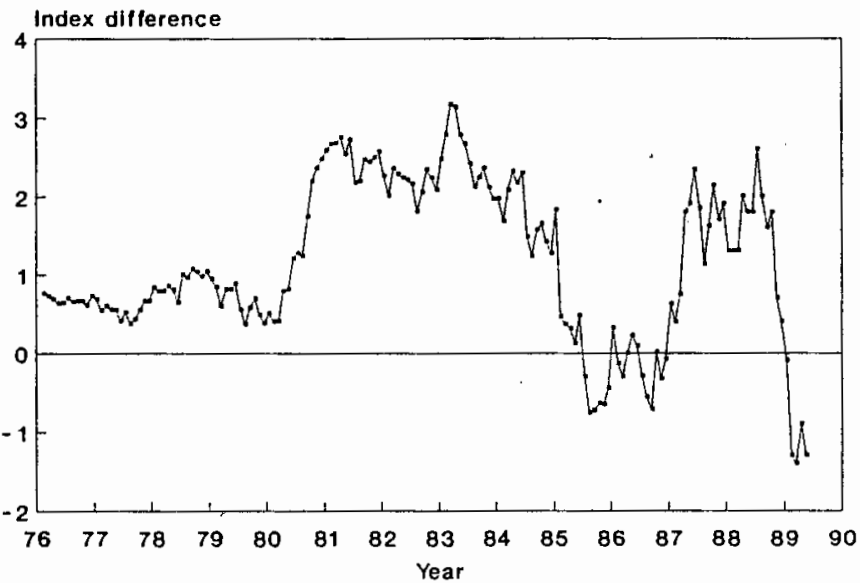

Figure 11: $\quad$ Cumulative increase in Basic income, CPI accumulated 6-monthly, base month: Feb 83

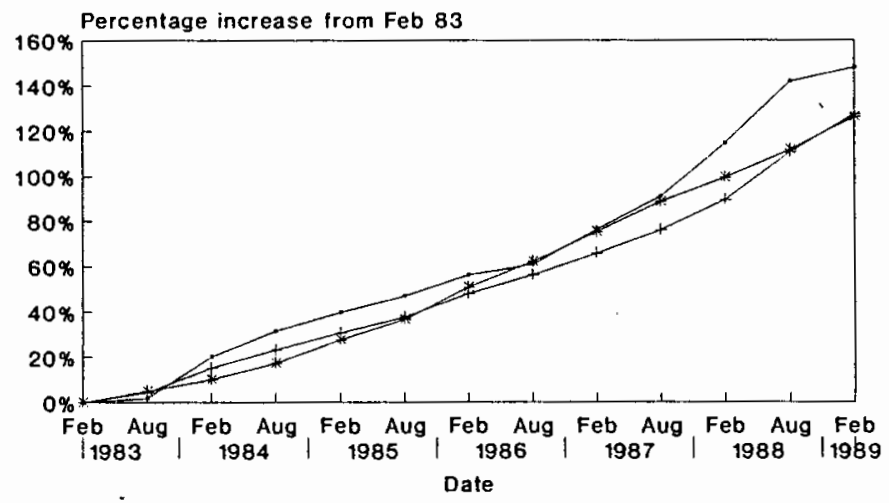

$\longrightarrow$ Grade 19 - $\longrightarrow$ Grade 15 CPI 


\section{APPENDIX A}

DYNAMIC REPAYMENT OF LOANS MODEL

\section{Layout of the spreadsheet}

A $B$

1 Progressive annuity model

2

3

4 Years of growth

5 Installment growth rate

6 Term of bond

7 Annual interest rate

8 Amount borrowed

9

11

12

13

14

15

16

17

18

19

20

21

22

23

24

25

26

27

28

29

30

31

32

33

34

48

49

50

11000,00

$2 \quad 1047,42$

31089,06

41122,25

$5 \quad 1143,61$

$6 \quad 1148,93$

$7 \quad 1132,98$

$8 \quad 1113,84$

$9 \quad 1090,88$

$10 \quad 1063,32$

$11 \quad 1030,24$

12990,55

$13 \quad 942,93$

$14 \quad 885,78$

$15 \quad 817,20$

16

734,90

636,15

17

18

19

517,64

375,43

20
C

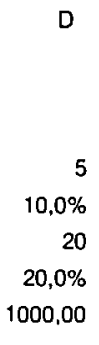

\section{Period Open Bal 0}

Interest

200,00

209,48

217,81

224,45

228,72

229,79

226,60

222,77

218,18

212,66

206.05

198,11

188,59

177,16

163,44

146,98

127,23

103,53

75,09

40,96
Instal. Cap Redem

152,58

167,84

184,63

203,09

223,40

245,74

245,74

245,74

245,74

245,74

245,74

245,74

245,74

245,74

245,74

245,74

245,74

245,74

245,74

245,74

$-41,64$

$-33,19$

$-21,36$

$-5,33$

15,95

19,14

22,97

27,56

33,07

39,69

47,63

57,15

68,58

82,30

98,76

118,51

142,21

170,65
E
Property growth ra
Size of loan
Fixed installment
Initial instal.
Final instal.
Maximum owing
Year of max owing

\begin{tabular}{lr}
\multicolumn{1}{c}{ F $\quad$ G } & $H$ \\
Property growth ra & $1,0 \%$ \\
Size of loan & $90,0 \%$ \\
Fixed installment & 205,36 \\
Initial instal. & 152,58 \\
Final instal. & 245,74 \\
Maximum owing & 1148,93 \\
Year of max owing & 5
\end{tabular}
End Bal Cum Int Cum Redem 1000,00

1047,42

1089,06

200,00

$-47,42$

1122,25

409,48

$-89,06$

627,30

$-122,25$

1143,61

851,74

$-143,61$

1148,93

1080,47

$-148,93$

1132,98

1310,25

$-132,98$

1113.84

1536,85

$-113,84$

1090,88

1759,62

$-90,88$

1063,32

1977,79

$-63,32$

1030.24

2190,46

2396,50

$-30,24$

990,55

2594,62

9,45

57,07

88578

2783,20

114,22

817,20

2960,36

182,80

734.90

3123,80

265,10

636,15

3270,78

363,85

517,64

3398,01

482,36

375,43

3501,53

624,57

204,78

3576,62

795,22

$0,00 \quad 3617,58$

1000,00 


\section{Formulas in the cells}

\begin{tabular}{|c|c|c|}
\hline Cell address: & [Range Name] & Formula \\
\hline D4: & [JARE] & 5 \\
\hline D6 & [TERMYN] & 20 \\
\hline H3: & & $@ P M T(D 8, D 7, D 6)$ \\
\hline H4: & & + AANV \\
\hline H5: & & @MAX(D12..D49) \\
\hline H6: & & @MAX(F12..F49) \\
\hline H7: & & $@ M A X(112.149)$ \\
\hline D8: & [LENING] & @NPV(D7,D12..D31) \\
\hline E8: & & 1000/LENING \\
\hline F8: & [FAKTOR] & 1.5258282407 \\
\hline C12: & & $+B 12 \star \$ D \$ 7$ \\
\hline D12: & [AANV] & 100*FAKTOR \\
\hline E12: & & + AANV-C12 \\
\hline F12: & & $+B 12-E_{12}$ \\
\hline G12: & & $+\mathrm{C}_{12}$ \\
\hline H12: & & $+\mathrm{E} 12$ \\
\hline 112: & & $@ \mathrm{~F}(\mathrm{~F} 12=\$ \mathrm{H} \$ 6 . \mathrm{A} 12.0)$ \\
\hline B13: & & $+F 12$ \\
\hline C13: & & $+B 13^{\star} \$ D \$ 7$ \\
\hline D13: & & $+\operatorname{AANV}^{\star}(1+\$ D \$ 5)$ \\
\hline E13: & [BULK] & $+D 13-C_{13}$ \\
\hline F13: & & $+B 13-B U L K$ \\
\hline G13: & & $+\mathrm{G}_{12}+\mathrm{C}_{13}$ \\
\hline H13: & & $+\mathrm{H} 12+$ BULK \\
\hline 113: & & $@ \mathrm{IF}(\mathrm{F} 13=\$ H \$ 6, \mathrm{~A} 13,0)$ \\
\hline A14: & [PER] & 3 \\
\hline B14: & & $+F 13$ \\
\hline C14: & & $+\mathrm{B} 14^{\star} \mathrm{SDS7}$ \\
\hline D14: & & $+D 13^{*}(1+\$ D \$ 5)$ \\
\hline E14: & & $+D 14-C 14$ \\
\hline F14: & & $+B 14-E_{14}$ \\
\hline G14: & & $+G_{13}+C_{14}$ \\
\hline H14: & & $+H 13+E 14$ \\
\hline 114: & & $@ \mid F(F 14=\$ H \$ 6, P E R, 0)$ \\
\hline
\end{tabular}

Formulas in $\mathrm{A} 14$ to 114 are repeated in all subsequent rows to make up the full term 
http://orion.journals.ac.za/

101

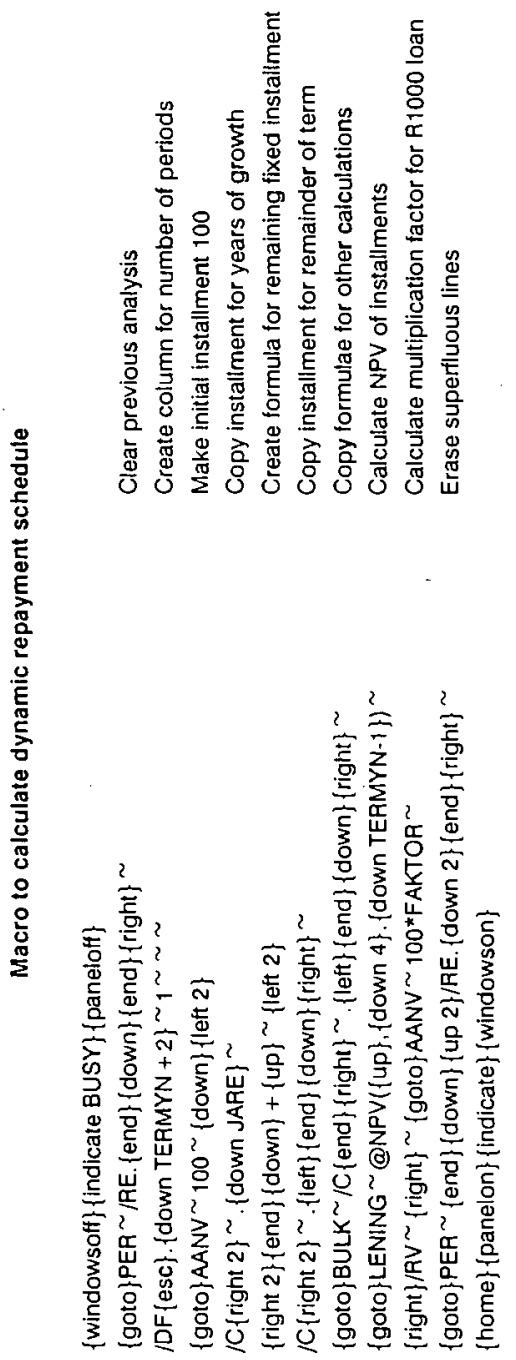

